\title{
Macroeconomic risk factors and the role of mispriced credit in the returns from international real estate securities
}

\author{
Andrey Pavlov ${ }^{\mathrm{A}}$, Eva Steiner ${ }^{* \mathrm{~B}}$ and Susan Wachter ${ }^{\mathrm{C}}$ \\ A Simon Fraser University \\ ${ }^{\mathrm{B}}$ University of Cambridge \\ ${ }^{\mathrm{C}}$ University of Pennsylvania
}

\begin{abstract}
The benefits of diversification from international real estate securities are generally well established. However, the drivers of international real estate securities returns are insufficiently understood. We jointly examine the empirical implications of three major international asset pricing models that account for broad macroeconomic risk factors. In addition, we develop the hypothesis that an indicator of mispriced credit is significant in explaining the time series variation in international real estate securities returns. We employ the returns generated by a large sample of firms from 20 countries over the period 1999 to 2011 to test our hypothesis. We find support for the predictions of the major international asset pricing models. We also find evidence in favour of our hypothesised link between local credit conditions and the performance of international real estate securities.
\end{abstract}

Key words: Real estate investment firms, International asset pricing, Macroeconomic risk factors, Credit markets

\footnotetext{
* Corresponding Author: Department of Land Economy, The University of Cambridge, 19 Silver Street, Cambridge CB3 9EP, United Kingdom, es434@cam.ac.uk
} 


\section{Introduction}

What are the factors that drive the returns on international real estate securities? Empirical research has established the importance of the world stock market, regional influences, and firm-level characteristics such as size and value effects. ${ }^{1}$ However, Worzala and Sirmans (2003) conclude that the return drivers of international real estate securities are insufficiently understood. Research in international asset pricing highlights the role of macroeconomic factors, in particular a global market factor, inflation and foreign exchange rate risks (Grauer, Litzenberger, and Stehle, 1976; Sercu, 1980; Solnik, 1974). Yet, the canonical influence of macroeconomic factors on international real estate securities has not been established. ${ }^{2}$

In this paper, we jointly examine the empirical implications of the major international asset pricing models for the time series of international real estate securities returns. Moreover, we employ this framework to identify the influence of an additional macroeconomic factor that derives from the local credit market conditions and is intricately linked to the local real estate markets. We develop a testable hypothesis of how local credit market conditions and the mispricing of credit may impact the returns from international real estate securities. Consequently, we augment our international asset pricing model with a measure of mispriced credit. This measure captures underpriced default risk and is based on the asset price response to changes in the lending spread in an economy. ${ }^{3}$

The relationship between macroeconomic risk factors, credit market conditions and firm performance is arguably of particular interest in the context of real estate securities. These securities represent an interesting case study for two main reasons. Firstly, real estate is especially sensitive to credit market conditions as the asset class is characterised, amongst others, by fixed short-run supply and high capital intensity. Secondly, investors commonly employ real estate stocks in order to gain exposure to the underlying direct real estate, the performance of which is linked to the macroeconomy. As a result, the structure of the empirical relationships between macroeconomic risk factors, credit market conditions and the performance of real estate securities seems to be a natural but, to date, under-researched question.

\footnotetext{
1 See, for example, Bond, Karolyi, and Sanders (2003); Case, Goetzmann, and Rouwenhorst (1999); Eichholtz and Huisman (2001); Eichholtz, Huisman, Koedijk, and Schuin (1998); Hamelink and Hoesli (2004); Ling and Naranjo (2002).

2 A notable exception in this context is Bardhan, Edelstein, and Tsang (2008) who consider the local term spread and an indicator of a country's economic openness.

3 Allen (2001); Allen and Gale (1999); Pavlov and Wachter (2009).
} 
We primarily establish empirical evidence for the role of macroeconomic factors in explaining the time series of international real estate returns. In addition, our analysis also contributes to the literature on the relationship between credit market conditions and the performance of real estate and financial assets. Research to date has established the role of the credit volume supplied in an economy in driving real estate values (Glick and Lansing, 2010; Mian and Sufi, 2009; Pavlov and Wachter, 2011b). However, credit volume is endogenously determined within the economy. Without information on the pricing of credit it is impossible to identify whether credit volume changes as a result of demand or supply effects, such as reduced credit standards, which are commonly named as a driver of unsustainable real estate values. We contribute to this debate by focusing on the relationship between the pricing of debt, the value of real estate assets and how this filters through to the performance of financial assets that are linked to real estate assets.

Further, research has only begun to attempt to identify the driving forces behind the complex interactions between credit and real estate values. The existing literature in this area largely focuses on the residential sector. There are relatively fewer studies to date that examine commercial real estate. ${ }^{4}$ Here, we expand on this research by examining firm returns in the context of an international asset pricing model that includes proxies for aggregate risk factors such as the return on the world stock market as well as residual country-level stock market factors and other macroeconomic variables. Our framework allows us to control for the argument put forward in Favilukis, Kohn, Ludvigson, and van Nieuwerburgh (2012) that aggregate risk drives real estate values via an easing of credit standards and thus expansion of credit availability. Therefore, our set-up enables us to contribute to this literature by isolating the effects related to the pricing of credit that are at play within the real estate sector, net of changes in the perception of aggregate risk in the economy.

The remainder of this article is structured as follows. Section 4 reviews the related literature. Section 7 describes our empirical methodology. Section 12 outlines data and descriptive statistics. Sections 14 and 18 discuss results and robustness tests. Section 18 concludes.

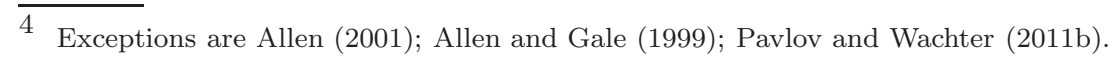




\section{Related literature}

The conceptual background for this study is given by the international asset pricing literature. Three seminal models describe international security returns as a function of a global market factor, inflation and foreign exchange rate risk (Grauer, Litzenberger, and Stehle, 1976; Sercu, 1980; Solnik, 1974). Consistent with evidence from the US stock market, firm characteristics such as size and book-to-market ratio also appear to capture a significant proportion of the cross-sectional and time series variation in international stock returns (Fama and French, 1998, 2011). However, it remains unclear whether underlying fundamental risks (Fama and French, 1996) or behavioural biases (Daniel and Titman, 1997; Lakonishok, Shleifer, and Vishny, 1994) drive the premiums on these factors. Further, there is an ongoing debate about whether any international factor, macroeconomic or characteristic-based, derives its premium locally or globally (Bekaert, Hodrick, and Zhang, 2009; Fama and French, 1998; Griffin, 2002; Hou, Karolyi, and Kho, 2011). Multi-factor asset pricing models appear to explain a significant proportion of the variation in real estate security returns in a domestic (US) context (Chan, Hendershott, and Sanders, 1990; Karolyi and Sanders, 1998; Ling and Naranjo, 1997, 1999; Ling, Naranjo, and Ryngaert, 2000). Against this background, and with increasing data availability, the real estate literature has begun to address some of these questions in the context of international real estate asset pricing.

A number of empirical studies examine the evidence for global versus regional factors in explaining the returns on international real estate securities (Case, Goetzmann, and Rouwenhorst, 1999; Eichholtz and Huisman, 2001; Eichholtz, Huisman, Koedijk, and Schuin, 1998; Ling and Naranjo, 2002). This evidence generally supports the notion of global pricing alongside the significance of a residual local or regional market factor that persists in the presence of the global factor. A parallel stream of studies expands the set of potential predictors to international firm-level characteristic factors and presents evidence that generally supports the importance of the value and size effects (Bond, Karolyi, and Sanders, 2003; Eichholtz and Huisman, 2001; Hamelink and Hoesli, 2004). There is also empirical evidence for the significance of macro variables such as the local term spread or an indicator of a country's economic openness in pricing international real estate securities (Bardhan, Edelstein, and Tsang, 2008). Nevertheless, the literature to date stops short of jointly estimating the relative impact of the three factors derived from the international asset pricing models on the time series of international real estate security returns. 
Research suggests that the relationship between the returns on (international) real estate securities and the performance of the underlying direct real estate markets is weak. ${ }^{5}$ This result seems puzzling as theory suggests that the two markets are linked through the relative cost of capital (Carlson, Titman, and Tiu, 2010).

In parallel, the meltdown of global real estate markets in 2008 has fuelled considerable interest in the factors that facilitate the rapid appreciation and subsequent decline of international real estate values. Theory predicts complex interactions between the real and financial sectors in propagating shocks through the economy (Bernanke, Gertler, and Gilchrist, 1996; Kiyotaki and Moore, 1997), but the direction of the relationship between credit and real estate values remains unclear. Research has established evidence that credit fuels house prices (Glick and Lansing, 2010; Mian and Sufi, 2009; Pavlov and Wachter, 2011b) and that house prices influence credit supply (Goetzmann, Peng, and Yen, 2012). Further, research on the nature of the mechanism through which credit conditions affect house prices is scarce. Our understanding of the channels through which financial intermediation, and especially the price of credit, rather than credit volume, affects global real estate values remains incomplete. ${ }^{6}$

We provide a comprehensive analysis that jointly examines the main empirically testable implications from the three major international asset pricing models as they pertain to global market risk, foreign exchange and inflation risk. Therefore, we offer an attempt to unify prior research into global versus local and macroeconomic factors in international real estate securities returns. We employ this framework in order to explore an additional return-driving factor. This factor relates to the potential systematic underpricing of put options embedded in non-recourse loans for real estate assets. ${ }^{7}$ We exploit data on global real estate firms in order to determine the influence of macroeconomic factors on firm returns and relate firm-level asset pricing to a potential mechanism of interaction between real and financial markets.

\footnotetext{
5 See, for example, Clayton and MacKinnon (2001, 2003); Giliberto (1990); Gyourko and Keim (1992); Ling and Naranjo (1999); Martin and Cook (1991); Myer and Webb (1993); Pavlov and Wachter (2011a); Seck (1996).

6 The distinction between residential and commercial real estate in this context is not trivial as the marginal price-setting investor in the commercial sector is likely to be an institution holding a diversified portfolio of assets. Theory predicts that a diversified investor will place relatively more importance on systematic risk and less importance on idiosyncratic risk.

7 As such, this study also builds on the prior work of Allen (2001); Allen and Gale (1999); Pavlov and Wachter $(2004,2006,2009)$.
} 


\section{Methodology}

\section{Macroeconomic risk factors}

Our primary objective is to establish empirical evidence for the role of macroeconomic factors in explaining the time series of returns from international real estate securities. ${ }^{8}$ We adopt the perspective of a US-investor in this study, focusing on US\$-denominated returns, US T-bills as the risk-free rate and foreign exchange rate risks measured relative to the US\$. We estimate the following global panel model, allowing for random security-specific effects, as indicated by a Hausman test:

$r_{j t}=\theta_{0}+\theta_{1} r_{w t}+\theta_{2} r_{c t}^{\perp}+\theta_{3} r_{e t}^{\perp}+\theta_{4} e_{t}+\theta_{5} \lambda_{t}+\theta_{6} i_{t}^{U S}+\omega_{j t}$

where $r_{j t}$ is the excess monthly total return over the risk free rate on security $j$. All predictors are expressed as excess returns over the risk free rate. The residual $\omega_{j t}=\varpi_{j t}+\xi_{j}$ contains security-specific effects. We cluster standard errors by firm to be robust to heteroskedasticity and autocorrelation (Hoechle, 2007; Petersen, 2009; Thompson, 2011). We also include year fixed-effects to account for latent macroeconomic shocks.

International asset pricing models typically consider firm returns to be positively related to a global market factor. We therefore include the returns on a global stock market proxy, $r_{w t}$, in our regression. Following Bond, Karolyi, and Sanders (2003), we add a residual country factor, $r_{c t}^{\perp}$, from the projection:

$r_{c t}=\alpha_{c}+\beta_{c} r_{w t}+\epsilon_{c t}$

where $r_{c t}$ is the monthly excess total return on country $c$ 's main stock market index over the risk free rate, $r_{w t}$ is the monthly excess world market return, and $\epsilon_{c t}$ is the residual representing the orthogonalised country factor $r_{c t}^{\perp}$. Similarly, we control for a residual real estate factor (Bond, Karolyi, and Sanders, 2003) from the projection:

$r_{e t}=\alpha_{e}+\beta_{e 1} r_{w t}+\beta_{e 2} r_{c t}+\nu_{e t}$

where variables are defined as in (2), $r_{e t}$ is the monthly excess total return on country e's EPRA/NAREIT listed real estate index over the risk free rate and $\nu_{e t}$ is the

8 We focus on the time series of returns instead of testing the cross-section as the number of cross-sectional units (countries) in the final sample is small (20 countries). 
residual representing the orthogonalised real estate factor $r_{e t}^{\perp}$.

Theory further predicts a positive relationship between exchange rate risk and security returns. We decompose the foreign exchange rates of our sample countries into a common and residual component. This approach helps reduce multicollinearity between commonly correlated exchange rates and preserves more information than using a broad index (Vassalou, 2000). Specifically, we project:

$r_{l t}=\delta_{l}+\sum \gamma_{l} r_{l t}+\eta_{l t}$

where $r_{l t}$ is the monthly change (logged ratio of the exchange rate at time $t$ over $t-1)$ in currency l's exchange rate relative to the US\$. We regress $r_{l t}$ on the changes in all remaining $L-1$ exchange rates. The $\eta_{l t}$ represent the residual components in currency $l$. We then obtain a time series of the average residual components $e_{t}$. We define the common component from (4) as $\kappa_{l t}=r_{l t}-\delta_{l}-\eta_{l t}$. Deviations from the period means $\kappa_{t}$ are collected in $\phi_{l t}$ to create a time series average $\lambda_{t}$, yielding:

$e_{t}=\frac{1}{L} \sum_{l=1}^{L} \eta_{l t} \quad$ and $\quad \lambda_{t}=\frac{1}{L} \sum_{l=1}^{L} \phi_{l t}$

International asset pricing models also consider inflation risks in international stock returns. We focus on the role of US inflation given the US-centric perspective of this study with the use of the US\$ as the numeraire currency, and the importance of the US economy in a global context. We filter US CPI data using an ARIMA $(0,1,1)$ specification (Fama and Gibbons, 1984; Vassalou, 2000). The residuals represent unexpected inflation, which we include in the regression as $i_{t}^{U S}$ (Vassalou, 2000).

\section{The role of mispriced credit}

Our second objective is to examine the effect of mispriced credit on the returns from international real estate securities. Pavlov and Wachter $(2004,2006)$ show that mispricing of credit can occur when bank managers' myopia, limited liability, deposit insurance, or a combination of these factors, renders the market for credit inefficient.

Market inefficiency violates the Modigliani and Miller (1958) assumptions and thus allows the link between the prices of different forms of capital to break down. As a result, the price of credit can vary independently of the price of other forms of capital traded in efficient markets, especially equity. We consider the case where credit 
market inefficiency manifests in underpricing of the put option that is embedded in non-recourse loans and whose value compensates the lender for default risk.

Our main hypothesis is primarily based on the work of Pavlov and Wachter (2009) who argue that underpriced credit inflates the value of real estate assets and in addition makes real estate markets relatively more sensitive to negative demand shocks. We propose that this model has a more general implication for the returns on listed real estate investment firms. If firms exploit underpriced debt, this produces excess free cash flow. Firms may use this excess cash to purchase real estate at the inflated values. Firms may also over-invest and pursue inefficient projects. Managers may employ such a strategy in an attempt to build corporate empires (Jensen, 1986, 1993; Jensen and Meckling, 1976). ${ }^{9}$ Empire building commonly detracts from firm value as it is contrarian to shareholder interests. ${ }^{10}$

Pavlov and Wachter (2009) develop a market-based symptom of underpriced credit that is exploited in the market. We hypothesise an inverse relationship between current firm returns and this underpricing symptom in the last period. Investors disapprove of activities that represent an inefficient use of their funds (Jensen, 1986, 1993; Jensen and Meckling, 1976). The underpricing symptom that investors can observe using past firm returns allows them to assess to some extent whether managers engage in inefficient financing activities enabled by underpriced credit. Investors can penalise managers for these activities by bidding down the price of the stock, depressing returns in the current period. We expect that firms that exploit underpriced credit underperform relative to those firms that do not exploit inefficient credit markets. In order to test this hypothesis, we augment the asset pricing model described in (1) with the underpricing variable, $\rho_{j t}$.

Pavlov and Wachter (2009) suggest that a negative correlation between changes in the default spread and firm returns indicates underpricing of credit exploited by the firm. The default spread declines either due to a reduction in the expected future volatility of firm returns or underpricing of default risk. Lenders and borrowers have a strong incentive to hide underpricing. No lender would admit to charging too little for a loan, and no borrower would ever suggest that their business is riskier than

9 For instance, Ghosh, Giambona, Harding, and Sirmans (2011) find evidence consistent with empirebuilding in REIT capital structure choices.

10 While it would be interesting directly to examine the impact of over-investment, we believe that this is beyond the scope of this paper. In the context of this study, it would be very difficult to explicitly measure over-investment driven by underpriced credit as we cannot observe a counter-factual outcome as to what managers would have done in the absence of mispriced credit. 
implied by their borrowing rate. It is therefore impossible for outsiders to distinguish between the two causes of declining default spreads. We need to identify a signal that responds differentially to the two possible causes of default spread declines.

One such variable is the equity price of the firm, assumed to be efficient. If the default spread declines because the future expected volatility of the firm declines, there is little impact on the equity price. Marginal equity investors are diversified and individual volatility concerns them only through its impact on the covariance with the broad market. This effect is likely small.

On the other hand, if the default spread declines because the firm is accessing underpriced financing, this substantially impacts the equity price. Underpriced financing is no different than any other underpriced input, and it benefits the owners dollar for dollar. If underpricing is prevalent in the economy, then it lifts the asset prices for all assets in fixed supply, such as real estate. This further benefits the equity holders of real estate firms.

In summary, equity prices increase substantially if default spreads fall because of underpricing, and change little if default spread changes rationally in response to changes in firm volatility (which is diversifiable). Therefore, credit underpricing generates a negative correlation between equity returns and changes in default spreads, while correct pricing generates little or no correlation. Therefore, we can use the correlation between equity returns and changes in the default spread as an observable and objective symptom of underpricing. The above reasoning is formally laid out in Pavlov and Wachter (2009).

We calculate this correlation as follows:

$\rho_{j t}=\operatorname{corr}\left(r_{j}, \Delta_{c}^{D}\right)$

where $r_{j}$ is a column vector containing the monthly total returns on security $j$ from time $t-24$ to $t$ and $\Delta_{c}^{D}$ is a column vector containing the monthly changes in the default spread in security $j$ 's domicile $c$ over the same period. ${ }^{11}$

We proxy the default spread using the spread in country c's main lending and deposit rates (Pavlov and Wachter, 2009). Each element in the vector $\rho_{j t}$ corresponds to a

\footnotetext{
$\overline{11}$ The focus on the lending spread in the domicile might introduce a bias for firms that invest and thus potentially borrow in countries outside their domicile. However, there appears to be only a small number of firms in this category.
} 
monthly observation of a rolling 24 -month correlation value. ${ }^{12}$

We specify the augmented asset pricing model with the lagged values of the inverse of $L \cdot \rho_{j t}$ :

$r_{j t}=\theta_{0}+\theta_{1} r_{w t}+\theta_{2} r_{c t}^{\perp}+\theta_{3} r_{e t}^{\perp}+\theta_{4} e_{t}+\theta_{5} \lambda_{t}+\theta_{6} i_{t}^{U S}+\theta_{7} L . \rho_{j t}^{I n v}+\omega_{j t}$

If firms exploit underpriced debt, they will exhibit positive values of $\rho_{j t}^{I n v}$. We anticipate that these firms underperform relative to their peers and expect a negative sign for the coefficient of the inverse underpricing variable $\rho_{j t}^{I n v}$. The fact that we lag $\rho_{j t}^{I n v}$ also helps alleviate concerns surrounding a potential tautology between the dependent variable and this predictor containing a function of firm returns.

Note that the underpricing symptom does not mechanically force a firm exhibiting the symptom to under- or outperform. To see this, recall that the symptom is based on the correlation between changes in the default spread and stock returns. A firm can quite easily exhibit the correlation and underperform in the long run, as we hypothesise. Mechanically, a firm can also exhibit the symptom and outperform. In other words, a firm that underperforms on average over the study period can still have short-term fluctuations, positive or negative, depending on the most recent changes in the default spread in the economy. Even a firm without any positive return events can exhibit a negative correlation between returns and spreads simply based on the variation in the magnitude of negative returns, as the formula for correlation subtracts the mean of each series.

We also estimate this model with the underpricing symptom calculated on the basis of the residual returns filtered using the asset pricing model in (1) instead of the raw returns as described in (6).

\section{Control variables}

We control for firm leverage using semi-annual data on total debt-to-equity ratios, obtained from $S N L$. We include the debt-to-equity ratio as potentially highly levered firms may be more sensitive to changes in the lending spread even in the absence of mispriced credit or without exploiting any mispriced credit that may be present.

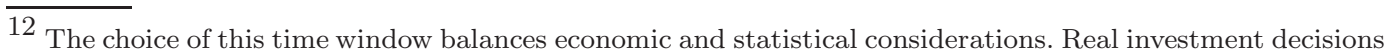
need to adjust to changes in the cost of borrowing and the results must manifest in returns, suggesting a substantial lag before an effect becomes observable. At the same time, we aim to keep the window short in order to alleviate smoothing effects. Our main results are robust to employing alternative windows, such as 12 and 18 months, which we believe are reasonable given the overall length of the sample.
} 
We control for firm size, proxied by the log of the annual market capitalisation of the firm in millions of current US\$ from $S N L$ as this variable may potentially impact on the responsiveness of firm returns to macroeconomic shocks and thus influence any relationship we identify between firm performance and the variables of interest.

We also include an indicator variable that takes the value of one if a firm has elected the REIT status in order to control for potential differences between REITs and unregulated real estate investment firms in the sample, as our study focuses on a period when REIT regimes were introduced in many of the sample countries. The underlying information is from $S N L$.

Further, we control for country-level governance using the dataset on Worldwide Governance Indicators (WGI) provided by the World Bank, as mispriced credit may be more easily exploited in countries where governance is weak. The WGI data comprises six separate governance measures. We have aggregated these measures into a single, equally-weighted average per country and year. Prior to 2002, the WGI were published on a bi-annual basis. In these cases, we have included the results from a linear interpolation between the dates available to fill missing values.

Lastly, we include year- and country-fixed effects in order to capture latent economic shock factors and country-specific influences, such as changes in legislation.

\section{Data}

Or sample comprises the monthly total returns on all listed real estate investment firms on SNL Financial. Macroeconomic data on real GDP, CPI and deposit as well as lending rates is from the IMF, the World Bank and Global Financial Data (GFD). Monthly total returns on country-level and world stock market proxies, EPRA/NAREIT country-level listed real estate indices and foreign exchange rate data are obtained from Datastream. We include the returns on the 1-month US treasury bill as proxy for the risk-free rate. ${ }^{13}$

The SNL global database is comprehensive from 1999 onwards. We begin the full study period in 1999 and end in 2011, covering a full economic real estate cycle. Return data and GDP are denominated in US\$ and all foreign exchange rates are expressed relative to the US\$. The initial sample contains data on 585 firms from 20 countries, comprising of a total of 60,261 firm-month return observations.

\footnotetext{
$\overline{13}$ The data is obtained from http ://mba.tuck.dartmouth.edu/pages/faculty/ken.french/data_library.html
} 
We construct our sample as an unbalanced panel in order to mitigate any survivorship bias. Elton, Gruber, and Blake (1996) define survivorship bias as the tendency for failed firms to be excluded from performance studies, producing skewed results as only firms which were successful enough to survive until the end of the period are included. We include firms in our sample for as long as they existed.

Table 1 provides information on the composition of the sample. The majority of the firms in our sample are from the USA (164) and the UK (93), followed Hong Kong (49) and Singapore (44), Canada (43) and Japan (42). The largest sample firms are domiciled in the USA, Hong Kong, Japan, Australia, France and Spain.

The average return across all firms is $0.05 \%$. Countries with above average returns include Singapore (0.2\%) and Hong Kong (0.6\%), Sweden (0.3\%) and France (0.5\%), as well as the North American markets in the USA (0.5\%) and Canada (0.9\%). Markets with below-average performance include mainly the European markets such as the UK (-0.8\%), Italy (-2\%) and Spain (-1.1\%), but also Australia (-0.4\%). The average standard deviation of monthly returns is $13.5 \%$. Countries with above-average return volatility largely coincide with the countries showing poor performance over the study period. Low-volatility markets are mainly the mature European countries such as Belgium (5.3\%), Switzerland (4.7\%) or Finland (9.0\%).

Over the full study period, the median return tends to exceed the mean in some countries, suggesting that negative outliers may bias the mean returns that may intuitively appear low in some cases. Table 2 presents the monthly mean total return by sub-periods and shows that the period prior to the recent crisis produces on average higher and less volatile return values, more consistent with a priori expectations. ${ }^{14}$

Panel (a) of Table 3 describes the macroeconomics control variables. The risk-free rate, proxied by the return on 1-month US T-bills, averages $0.2 \%$ during the study period. On average, the MSCI World delivers $0.2 \%$ total monthly return. The country and real estate residuals do not seem to offer a positive premium over the risk free rate during our study period. The residual and common currency factors are slightly negative $(-0.2 \%)$. US inflation averaged $0.2 \%$ per month during the study period. The mean country governance score is 1.4. Panel (b) presents the firm-level controls we include. The mean debt-to-equity ratio is 1.9 ; the mean firm size is US $\$ 1.9 \mathrm{bn}$, the mean rate of investment is $3.5 \%$, and c. $48 \%$ of the observations are from REITs.

\footnotetext{
$\overline{14}$ Returns are denominated in US\$. The relative performance of the firms across the sub-periods remains consistent when returns are measured in local currency.
} 
Table 4 describes the underpricing variable by country. The mean is slightly negative for France, Italy, Japan, Sweden, Switzerland and the USA, suggesting that these countries on average exhibit the underpricing symptom. The standard deviations of the underpricing variable are in excess of $20 \%$ for most countries. This fact suggests significant variation of the underpricing variable. Pavlov and Wachter (2009) suggest that a negative correlation between changes in the default spread and firm returns indicates the exploitation of underprices credit. Figure 1 shows that the global average of the underpricing variable was negative in the run-up to the recent crisis, suggesting that firms were able to exploit underpriced debt in this period.

Table 5 reports the pairwise correlations between the predictors and generally shows low levels of correlation. The correlation between investment growth and underpricing is positive, suggesting that managers may exploit underpriced credit and simultaneously invest more.

\section{Results}

Table 6 presents the main regression results for the full study period 1999-2011. ${ }^{15}$ Specification (1) corresponds to the augmented global asset pricing model. Specification (2) employs the lagged inverse underpricing variable to predict the country residual in the model. In specification (3), we replace the original underpricing variable with an alternative based on the residual returns that have been filters using the general international asset pricing model that considers market, inflation and exchange rate factors. Specification (4) includes a dummy variable to indicate firms that exploit underpriced credit to a significant degree, measured as $\rho^{I n v}>0.2$.

Consistent with theory and empirical research in industrial stocks (Hou, Karolyi, and Kho, 2011; Vassalou, 2000), the global stock market is highly significant in explaining the time series of international real estate securities returns. This finding is also consistent with previous research in real estate securities (Bond, Karolyi, and Sanders, 2003; Ling and Naranjo, 2002). The coefficient is approximately one, suggesting that international real estate securities returns respond almost directly proportionally to fluctuations in the world stock market.

We also find evidence for the significant positive impact of a country residual on the

\footnotetext{
15 The results are robust to focusing on the period following the introduction of US REITs into the broader stock market indices in 2001, which may have influenced investor awareness with regard to listed real estate investment firms, that is the sub-period 2002-2011. The results are also robust to focusing on the period prior to the onset of the global financial crisis, that is the sub-period 2002-2007.
} 
time series of international real estate securities returns. Our result is consistent with the view that there are local stock market factors that drive real estate securities returns in a country beyond the stock market fluctuations captured in the global stock market proxy (Bond, Karolyi, and Sanders, 2003; Ling and Naranjo, 2002).

The residual performance of a country's real estate securities index, net of the influence of the global and local stock markets, also seems positively related to the time series of international real estate securities returns (Bond, Karolyi, and Sanders, 2003; Ling and Naranjo, 2002). This finding supports the notion of real estate securities as a diversifying asset class relative to industrial stocks.

The common component of foreign exchange rate fluctuations appears to be significantly positively related to the time series of international real estate securities returns. This finding is consistent with Vassalou (2000) and implies that during the study period, investors were better off not hedging exchange rate exposure as hedging may have eliminated the positive return response to these fluctuations.

US inflation has a significantly positive impact on the returns from international real estate securities. This finding implies that these securities appear to be able to provide a hedge against US inflation, consistent with findings reported in Vassalou (2000) for general stocks. Country governance generally appears to be inversely related to excess firm returns, suggesting that investors earn a positive risk premium for exposure to countries where governance is weaker. Firm size seems to be significantly positively related to excess firm returns, suggesting that larger firms outperform smaller firms. ${ }^{16}$ Lastly, REIT status appears to be positively related to excess firm returns, suggesting that REIT firms on average outperform their nonREIT counterparts.

The lagged inverse underpricing symptom seems significantly negatively related to the time series of international real estate securities returns. The returns on firms that exploit underpriced credit will have a negative correlation with changes in the lending spread in their respective countries. Those firms are likely to underperform relative to their peers. On the other hand, the returns on firms that do not exploit underpriced credit will have a non-negative correlation with changes in the local lending spread and do not systematically underperform. This mechanism is

\footnotetext{
16 This finding generally appears inconsistent with the general asset pricing literature suggesting that smaller firms tend to outperform larger firms (Fama and French, 1993). However, small stocks tend to outperform big stocks only over long periods and in relatively stable conditions. In a period such as the recent crisis, small stocks could easily underperform.
} 
captured in the negative sign of the coefficient on the lagged inverse underpricing variable. In other words, investors are able to observe the relationship between past firm returns and the local lending spread and assess whether firms exploit underpriced credit using the information set available at a given time. Investors are then able to adjust their pricing of the firm's equity and bid down the price of firms that exploit underpriced credit. Note however that the symptom we employ appears to be building up slowly. Investors require sufficient time to observe the correlation between firm returns and changes in the default spread in order to assess any exploitation of underpriced credit before bidding down the stock.

This relationship is consistent with the loan underpricing theory of Pavlov and Wachter (2009). When property owners take advantage of underpriced credit, they benefit in the short-run but expose themselves to long-term difficulties for two reasons. First, the underpriced credit is likely to disappear eventually, leaving them exposed to cost of credit increases even if the overall interest rates in the economy have not changed.

Second, operating in a market where underpriced credit is prevalent is risky, as this market is likely to experience larger price declines in an economic downturn. Managers of publicly traded real estate companies appear to exploit underpriced credit as they can reap the benefits of short-term profitability and have limited downside. Shareholders, however, are interested in the long-term performance of the firm, and are not in favour of taking advantage of underpriced credit for a number of reasons. First, such borrowing increases the long-term vulnerability of the firm, and exposes it to larger downside risks. Second, a manager taking advantage of underpriced credit is also likely to engage in empire building, thus growing the firm beyond its optimal size and/or undertaking investments that would detract from firm value in the absence of underpriced credit. Therefore, firms that take advantage of underpriced credit appear to underperform.

Our results shed light on the overall link between credit conditions and asset prices. Much of the related existing literature focuses on the interaction between house prices and credit, but our approach is the first to study this interaction in the context of publicly traded companies. A number of studies document house price increases in the presence of cheap credit, and easing of credit in response to price increases. While it is not surprising that privately held real estate experiences increases and decreases in value and performance over the credit cycle, one might expect that the 
investors in publicly traded companies have the foresight to underweight firms that take advantage of underpricing at all times. ${ }^{17}$

Research commonly finds evidence for the significance of a country or regional residual (Bond, Karolyi, and Sanders, 2003; Ling and Naranjo, 2002). However, the literature has not yet established what drives this residual country factor.

Our results from employing the lagged inverse underpricing variable to predict the country residual in our asset pricing model, especially the high values of the rank statistics assessing instrument relevance and strength, suggest that the country residual may be partly driven by local credit market conditions (specification 2).

Further, we replace the original underpricing variable with an alternative based on the residual returns filtered using the general international asset pricing model that considers market, inflation and exchange rate factors. Our finding is robust to using the filtered series (specification 3).

We also include a dummy variable to indicate firms that exploit underpriced credit to a significant degree at a given point in time, measured as $\rho^{I n v}>0.2$ (specification 4). The constant indicates the risk-free rate of return that investors can earn beyond the returns generated through exposure to the macroeconomic and firm risk factors included in our model. The coefficient on the dummy variable indicates the marginal return that investors can earn by investing in the firm type corresponding to the indicator variable. The coefficient on the firm type dummy in our model is negative and significant, suggesting that investors can improve risk-adjusted returns by avoiding firms that exploit underpricing.

We have estimated a set of additional regressions including different versions of the underpricing dummy variable defined by a range of thresholds from 0.1 to 0.9 in steps of 0.1 (Table 7). Our main conclusions are robust to choosing different thresholds for the definition of the dummy variable. In addition, the sequence of dummy variables allow us to some extent to examine potential aspects of non-linearity in the relationship between the exploitation of underpriced credit and excess firm returns. Our results show that the coefficients of the dummy variables measured at different thresholds become increasingly negative as the threshold values increase.

\footnotetext{
17 This expectation would force such firms to underperform even during credit expansion periods. Instead, we find (in unreported results) that even publicly traded firms that exploit underpriced credit outperform during credit expansion periods. The implication is that publicly traded equity on its own does not seem to be able to eliminate the incentives for exploiting underpriced debt.
} 
We interpret this finding as evidence consistent with the notion that the increasing use of underpriced credit may have an increasingly negative impact on returns.

As far as the potential for improvements on risk-adjusted returns is concerned, the use of alternative thresholds for the definition of the dummy variable suggests that the marginal risk-adjusted return to be achieved by avoiding firms that exploit underpricing increases in the extent to which these firms exploit mispriced credit. ${ }^{18}$

However, this finding does not necessarily imply that firms that do not exploit underpricing are just as beneficial for improving investment performance as the firms that exploit underpriced credit have a detrimental impact on performance. Overall, this part of our analysis allows us to conclude that avoiding firms that exploit underpricing helps investors achieve better risk-adjusted returns, because these firms contribute negatively to risk-adjusted returns.

\section{Robustness tests}

We explore several perspectives on the robustness of our findings. Table 8 presents the results on these robustness tests. First, it is possible that the significance of the underpricing-related variables are driven by changes in the cost of debt. Our focus is on firms exploiting errors in the pricing of debt in the banking system. We include i) changes in the lending spread and ii) the lending rate in order to control for this effect, see Column 1. The change in the lending spread is not significant and does not detract from the significance of the underpricing variable. Also, the magnitude of the coefficient on the underpricing variable remains fairly stable as compared to the original specification. The lending rate itself is significant, but again does not detract from the significance of the underpricing variable, suggesting that our results are robust to controlling for different aspects of the cost of debt.

We control for the residual country general stock market performance, net of the impact of the global stock market. This variable arguably captures business cycles through the observed variation in the stock market return. However, we have added an interaction term between this country residual and the underpricing variable in order to gauge any potential differential relationships between underpriced credit and firm performance throughout different period of the business cycle, see Column 2. Our results remain robust to this additional control.

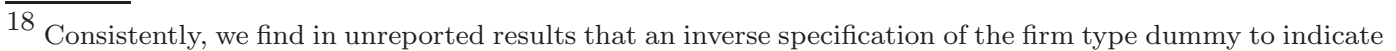
firms that do not exploit underpricing, measured as $\rho^{I n v}<-0.2$, is insignificant.
} 
We have also added the square of the underpricing variable to the regression model as an alternative measure of non-linearities in this relationship, see Column 3. Our main findings are robust to the inclusion of the square term, but this term itself is insignificant. However, the inclusion of a square term of a variable introduces significant collinearity with the main effect of this variable, potentially driving out the significance of the square term. Therefore, we focus our examination of potential non-linearities in the relationship between underpriced credit and firm returns on the sequence of dummy variables.

In addition, the coefficient of the inverse correlation could also capture the impact of momentum in excess firm returns. We have expanded our robustness tests to control for momentum, using the lagged 6-month buy-and-hold return on the sample firms, see Column 4. Our results are robust to controlling for return momentum.

Further, we examine the relationship between underpriced credit, investment behaviour and firm performance. We add an interaction term between underpriced credit and investment growth, measured as the annual change in net real estate investment relative to the beginning of period net real estate investment holdings from $S N L$. The coefficient on the interaction term between the two variables is negative and significant (Column 5). Our results are therefore consistent with the hypothesis that managers using underpriced credit underperform if they invest more.

Lastly, our hypothesis refers to underpricing of bank debt. This perspective implies that we expect this relationship to be specific to real estate firms since traditional industrial firms are less heavily reliant on bank debt. We should thus not observe a significant impact of the underpricing variable in the returns on industrial firms.

We replicate our analysis for a panel of non-real estate firms from the main stock market indices of the countries in which we find a significant relationship between the underpricing variable and the returns on listed real estate, namely Australia, Austria, Norway, New Zealand, Poland and Spain (Table 9). As expected, the underpricing variable is not significant. The mechanism of interaction between the real and financial sectors that we describe here relies on a direct response in the prices of real assets to changes in the credit conditions. This link is especially tight in the real estate sector. However, the real estate markets in the countries with significant underpricing of credit may be relatively smaller and, in some cases, less mature. 


\section{Conclusion}

The benefits of diversification through international real estate securities are well established, but their return drivers are unclear. To date, the nature and pricing rationale of international real estate securities are not fully understood. We jointly test the canonical implications of the three major international asset pricing models. Consistent with prior research, we find that international real estate securities are strongly related to a global market factor, but appear to offer diversification benefits as country and residual real estate factors remain highly significant.

International real estate securities correlate with common currency fluctuations but appear to provide a hedge against US inflation. We contribute to the literature on the drivers of the returns generated by international real estate securities by documenting the significant role of macroeconomic factors in explaining these returns.

In addition, we find evidence consistent with our hypothesis that the exploitation of underpriced debt is reflected in security returns and partly drives the residual country factors. This finding is robust to controlling for various aspects of the price of credit. We can also establish that this finding does not hold for firms outside the real estate sector where inefficiencies in the credit market are less relevant and where the links between the real and financial aspects of the industry are less tight. Having said that, we find that underpriced credit may be exploited especially in countries with smaller, less developed listed real estate sectors, suggesting that market maturity may have a role in limiting this phenomenon. More generally, our findings contribute to the literature on the interaction between real and financial markets by offering evidence on the role of the price of credit in determining asset returns.

Our findings further provide evidence in favour of the view that investors can employ information about past firm returns to assess to some extent whether managers engage in inefficient activities enabled by underpriced credit. Therefore, our findings imply that investors are able to make more efficient decisions about capital allocation by examining the underpricing variable employed in this study. Investors are able to identify and bid down the price of the firms that engage in empire building strategies.

Our results are also consistent with prior work suggesting that the use of underpriced credit exacerbates the asset price cycle both during the expansionary and contraction periods. This work is usually focused on non-traded assets or accounting measures of profitability or performance. Our study is the first, to the best of our knowledge, to 
use data on actively traded, publicly listed firms, that are commonly considered to be priced efficiently. The significant and persistent stock market under-performance that we document for companies using underpriced credit suggests that investors have the ability to ultimately detect the exploitation of underpriced credit.

Our analysis captures over-reliance on underpriced credit and its effect on firm performance. This effect may be driven by firms exploiting underpriced credit to purchase assets at inflated prices (Pavlov and Wachter, 2009) or by firms engaging in over-investment. Future research may consider directly modelling over-investment fuelled by underpriced credit and examining its impact on firm performance. 


\section{Acknowledgements}

We would like to thank the Editors, two anonymous reviewers as well as Andrew

Karolyi and Colin Lizieri for their insightful comments and suggestions, and Arthur Acoca-Pidolle for helpful research assistance. 


\section{References}

Allen, F. (2001): "Presidential Address: Do Financial Institutions Matter?," Journal of Finance, 56(4), 1165-1175.

Allen, F., And D. Gale (1999): "Innovations in Financial Services, Relationships, and Risk Sharing," Management Science, 45(9), 1239-1253.

Bardhan, A., R. Edelstein, And D. Tsang (2008): "Global Financial Integration and Real Estate Security Returns," Real Estate Economics, 36(2), 285-311.

Bekaert, G., R. J. Hodrick, and X. Zhang (2009): "International Stock Return Comovements," Journal of Finance, 64(6), 2591-2626.

Bernanke, B., M. Gertler, and S. Gilchrist (1996): "The Financial Accelerator and the Flight to Quality," Review of Economics and Statistics, 78(1), 1-15.

Bond, S. A., G. A. Karolyi, and A. B. Sanders (2003): "International Real Estate Returns: A Multifactor, Multicountry Approach," Real Estate Economics, 31(3), 481-500.

Carlson, M., S. Titman, And C. Tiu (2010): "The Returns Linkages for Private and Public Real Estate," Working Paper.

Case, B., W. N. Goetzmann, and K. G. Rouwenhorst (1999): "Global Real Estate Markets: Cycles And Fundamentals," Working Paper.

Chan, K. C., P. H. Hendershott, and A. B. Sanders (1990): "Risk and return on real estate: Evidence from equity REITs," AREUEA Journal, 18(4), 431-452.

Clayton, J., And G. MacKinnon (2001): "The time-varying nature of the link between REIT, real estate and financial asset returns," Journal of Real Estate Portfolio Management, 7(1), 43-54.

Clayton, J., and G. MacKinnon (2003): "The Relative Importance of Stock, Bond and Real Estate Factors in Explaining REIT Returns," Journal of Real Estate Finance and Economics, 27, 39-60, 10.1023/A:1023607412927.

Daniel, K., and S. Titman (1997): "Evidence on the characteristics of cross sectional variation in stock returns," Journal of Finance, 52(1), 1-33.

Eichholtz, P., And R. Huisman (2001): "The Cross Section of Global Property Share Returns," in A Global Perspective on Real Estate Cycles, ed. by S. J. Brown, and C. H. Liu, vol. 6 of The New York University Salomon Center Series on Financial Markets and Institutions, pp. 89-101. Springer US.

Eichholtz, P., R. Huisman, K. Koedijk, And L. Schuin (1998): "Continental Factors in International Real Estate Returns," Real Estate Economics, 26(3), 493509.

Elton, E. J., M. J. Gruber, and C. R. Blake (1996): "Survivorship Bias and Mutual Fund Performance," Review of Financial Studies, 9(4), 1097-1120.

Fama, E. F., AND K. R. French (1993): "Common risk factors in the returns on stocks and bonds," Journal of Financial Economics, 33(1), 3-56.

(1996): "Multifactor explanations of asset pricing anomalies," Journal of Finance, 51(1), 55-84.

(1998): "Value versus Growth: The International Evidence," Journal of Finance, 53(6), 1975-1999.

- (2011): "Size, Value, and Momentum in International Stock Returns," SSRN eLibrary.

FAma, E. F., And M. R. Gibbons (1984): "A comparison of inflation forecasts," Journal of Monetary Economics, 13(3), 327-348.

Favilukis, J., D. Kohn, S. C. Ludvigson, and S. van Nieuwerburgh (2012): "International Capital Flows and House Prices: Theory and Evidence," NBER 
Working Papers 17751, National Bureau of Economic Research.

Ghosh, C., E. Giambona, J. Harding, and C. Sirmans (2011): "How Entrenchment, Incentives and Governance Influence REIT Capital Structure," Journal of Real Estate Finance and Economics, 43(1), 39-72.

Giliberto, S. M. (1990): "Equity Real Estate Investment Trusts and Real Estate Returns," Journal of Real Estate Research, 5(2), 259-264.

GLick, R., AND K. J. LANsing (2010): "Global household leverage, house prices, and consumption," FRBSF Economic Letter.

Goetzmann, W., L. Peng, And J. Yen (2012): "The Subprime Crisis and House Price Appreciation," Journal of Real Estate Finance and Economics, 44(1), 36-66.

Grauer, F. L., R. H. Litzenberger, and R. E. Stehle (1976): "Sharing rules and equilibrium in an international capital market under uncertainty," Journal of Financial Economics, 3(3), 233 - 256.

Griffin, J. M. (2002): "Are the Fama and French Factors Global or Country Specific?," Review of Financial Studies, 15(3), 783-803.

Gyourko, J., And D. B. Keim (1992): "What Does the Stock Market Tell Us About Real Estate Returns?," Real Estate Economics, 20(3), 457-485.

Hamelink, F., AND M. Hoesli (2004): "What Factors Determine International Real Estate Security Returns?," Real Estate Economics, 32(3), 437-462.

Hoechle, D. (2007): "Robust standard errors for panel regressions with crosssectional dependence," Stata Journal, 7(3), 1-31.

Hou, K., G. A. Karolyi, And B.-C. Kho (2011): "What Factors Drive Global Stock Returns?," Review of Financial Studies, 24(8), 2527-2574.

Jensen, M. C. (1986): "Agency costs of free cash flow, corporate finance, and takeovers," American Economic Review, 76(2), 323-329.

Jensen, M. C. (1993): "The Modern Industrial Revolution, Exit, and the Failure of Internal Control Systems," Journal of Finance, 48(3), 831-80.

Jensen, M. C., And W. H. Meckling (1976): "Theory of the firm: managerial behavior, agency costs and ownership structure," Journal of Financial Economics, 3(4), 305-360.

Karolyi, G. A., And A. B. Sanders (1998): "The Variation of Economic Risk Premiums in Real Estate Returns," Journal of Real Estate Finance and Economics, 17(3), $245-262$.

Kiyotaki, N., And J. Moore (1997): "Credit Cycles," Journal of Political Economy, 105(2), 211-48.

Lakonishok, J., A. Shleifer, and R. W. Vishny (1994): "Contrarian Investment, Extrapolation, and Risk," Journal of Finance, 49(5), 1541-1578.

Ling, D. C., And A. NAranjo (1997): "Economic Risk Factors and Commercial Real Estate Returns," Journal of Real Estate Finance and Economics, 14(3), 283307.

LinG, D. C., AND A. NARANJo (1999): "The Integration of Commercial Real Estate Markets and Stock Markets," Real Estate Economics, 27(3), 483-515.

Ling, D. C., AND A. NARAnjo (2002): "Commercial Real Estate Return Performance: A Cross-Country Analysis," Journal of Real Estate Finance and Economics, 24(1-2), 119-42.

Ling, D. C., A. Naranjo, And M. D. Ryngaert (2000): "The Predictability of Equity REIT Returns: Time Variation and Economic Significance," Journal of Real Estate Finance and Economics, 20(2), 117-36.

Martin, J. D., And D. O. Cook (1991): "A Comparison of the Recent Performance of Publicly Traded Real Property Portfolios and Common Stock," Real 
Estate Economics, 19(2), 184-212.

Mian, A., AND A. Sufi (2009): "The Consequences of Mortgage Credit Expansion: Evidence from the US Mortgage Default Crisis," Quarterly Journal of Economics, 124(4), 1449-1496.

Modigliani, F., AND M. Miller (1958): "The cost of capital, corporate finance and the theory of investment," American Economic Review, 48(2), 261-297.

Myer, F. N., ANd J. R. WebB (1993): "Return Properties of Equity REITs, Common Stocks, and Commercial Real Estate: A Comparison," Journal of Real Estate Research, 8(1), 87-106.

PAvlov, A., AND S. M. WAChter (2004): "Robbing the Bank: Non-recourse Lending and Asset Prices," Journal of Real Estate Finance and Economics, 28(2), $147-160$.

(2006): "The Inevitability of Marketwide Underpricing of Mortgage Default Risk," Real Estate Economics, 34(4), 479-496.

- (2009): "Mortgage Put Options and Real Estate Markets," Journal of Real Estate Finance and Economics, 38(1), 89-103.

(2011a): "REITS and Underlying Real Estate Markets: Is There a Link?," SSRN eLibrary.

- (2011b): "Subprime Lending and Real Estate Prices," Real Estate Economics, 39(1), 1-17.

Petersen, M. (2009): "Estimating standard errors in finance panel data sets: comparing approaches," Review of Financial Studies, 22(1), 435-480.

SECK, D. (1996): "The Substitutability of Real Estate Assets," Real Estate Economics, 24(1), 75-95.

Sercu, P. (1980): "A Generalization of the International Asset Pricing Model," Revue de l'Association Française de Finance, 1(1), 91-135.

Solnik, B. H. (1974): "An equilibrium model of the international capital market," Journal of Economic Theory, 8(4), 500-524.

Thompson, S. B. (2011): "Simple formulas for standard errors that cluster by both firm and time," Journal of Financial Economics, 99(1), 1-10.

VASSALOU, M. (2000): "Exchange rate and foreign inflation risk premiums in global equity returns," Journal of International Money and Finance, 19(3), 433-470.

Worzala, E., and C. Sirmans (2003): "Investing in International Real Estate Stocks: A Review of the Literature," Urban Studies, 40(5-6), 1115-1149. 


\section{Tables and Figures}

Descriptive statistics for the country-level real estate securities, full study period (1999-2011)

\begin{tabular}{lrrrrrr}
\hline Country & Firms & Mean market cap. & Mean return & Median return & S.D. & N \\
\hline Australia & 29 & 2456.294 & -0.443 & 0.824 & 13.008 & 2970 \\
Austria & 7 & 976.743 & -0.863 & 0.245 & 12.355 & 703 \\
Belgium & 12 & 543.632 & 0.394 & 0.577 & 5.265 & 1386 \\
Canada & 43 & 863.933 & 0.886 & 1.077 & 11.797 & 4502 \\
Finland & 3 & 558.458 & 0.284 & 0.386 & 9.002 & 400 \\
France & 25 & 2337.066 & 0.452 & 0.408 & 10.771 & 3117 \\
Germany & 27 & -1.087 & 0.000 & 15.583 & 1970 \\
Hong Kong & 49 & 5431.961 & 0.634 & 0.542 & 13.784 & 4846 \\
Italy & 5 & -1.953 & -0.308 & 17.460 & 543 \\
Japan & 42 & 2797.452 & -0.144 & 0.243 & 11.146 & 3519 \\
Netherlands & 8 & 1339.411 & -0.618 & 0.000 & 11.585 & 952 \\
New Zealand & 3 & 525.231 & 0.630 & 0.687 & 4.063 & 313 \\
Norway & 3 & 853.528 & -0.566 & -0.303 & 10.921 & 230 \\
Poland & 2 & 1224.319 & 0.160 & 0.000 & 10.796 & 239 \\
Singapore & 44 & 1462.337 & 0.176 & 0.367 & 11.380 & 3915 \\
Spain & 8 & 2319.543 & -1.063 & -0.389 & 15.507 & 834 \\
Sweden & 13 & 944.921 & 0.273 & 1.180 & 12.403 & 1438 \\
Switzerland & 5 & 1208.937 & 0.288 & 0.386 & 4.740 & 566 \\
USA & 164 & 2156.313 & 0.509 & 1.147 & 12.423 & 19097 \\
UK & 93 & -0.795 & 0.000 & 13.672 & 8721 \\
Total & 585 & 0.057 & 0.523 & 13.485 & 60261 \\
\hline \hline
\end{tabular}

Table 1

The table presents descriptive statistics for a total of 585 sample firms from 20 countries, resulting in an initial sample size of 60,261 firm-month observations, recorded over the full study period January 1999 to December 2011. All firm-level information presented in this table is obtained from the SNL Financial Global Database. Firms indicates the number of firms included in the sample in a given country, as determined by the $S N L$ coverage. Mean market capitalisation refers to the average market capitalisation of the sample firms in a given country over the study period in millions of current US\$. The table also presents mean and median monthly total returns of the sample firms in percentage form, alongside their standard deviation (S.D.) and the number of observations (N). 
Descriptive statistics for the monthly total return on country-level real estate securities, selected sub-periods

\begin{tabular}{lrrrr}
\hline & \multicolumn{3}{c}{$\mathbf{2 0 0 2 - 2 0 1 1}$} & 2002-2007 \\
Country & Mean return & S.D. & Mean return & S.D. \\
\hline Australia & -0.499 & 13.272 & 1.410 & 6.022 \\
Austria & -1.097 & 13.291 & -0.120 & 4.736 \\
Belgium & 0.435 & 5.478 & 0.724 & 4.232 \\
Canada & 0.908 & 10.893 & 1.671 & 9.223 \\
Finland & 0.504 & 9.742 & 1.943 & 6.824 \\
France & 0.389 & 10.513 & 1.327 & 9.676 \\
Germany & -1.194 & 15.281 & 0.705 & 15.518 \\
Hong Kong & 0.653 & 13.826 & 2.071 & 12.881 \\
Italy & -2.856 & 17.459 & 0.540 & 7.901 \\
Japan & -0.236 & 10.815 & 1.449 & 8.899 \\
Netherlands & -0.749 & 12.512 & 0.951 & 5.125 \\
New Zealand & 0.630 & 4.063 & 1.131 & 3.693 \\
Norway & -0.486 & 11.67 & 1.331 & 6.449 \\
Poland & 0.461 & 10.834 & 2.413 & 10.36 \\
Singapore & 0.385 & 11.258 & 1.889 & 8.53 \\
Spain & -1.564 & 16.584 & 2.512 & 12.135 \\
Sweden & 0.295 & 12.485 & 1.625 & 9.751 \\
Switzerland & 0.355 & 4.797 & 0.705 & 3.756 \\
USA & 0.465 & 12.605 & 0.936 & 7.429 \\
UK & -1.041 & 14.206 & 0.563 & 9.151 \\
Total & -0.001 & 13.515 & 1.361 & 10.554 \\
\hline \hline
\end{tabular}

Table 2

The table presents descriptive statistics on the total monthly return for a total of 585 sample firms from 20 countries, resulting in an initial sample size of 60,261 firm-month observations. The return data is presented for two sub-periods, i) the period following the introduction of US REITs into the broader stock market indices, which may have influenced investor awareness with regard to listed real estate investment firms, that is the sub-period 2002-2011, and ii) the period prior to the onset of the global financial crisis, that is the sub-period 2002-2007. All firm-level information presented in this table is obtained from the SNL Financial Global Database. Monthly total returns of the sample firms are presented in percentage form, alongside their standard deviation (S.D.). 
Descriptive statistics for the control variables, full study period (1999-2011)

\begin{tabular}{|c|c|c|c|c|}
\hline \multicolumn{5}{|c|}{ Panel (a): Macroeconomic control variables } \\
\hline Variable & Mean & Median & S.D. & $\mathbf{N}$ \\
\hline Risk-free rate & 0.206 & 0.150 & 0.167 & 155 \\
\hline MSCI & 0.174 & 0.639 & 4.864 & 155 \\
\hline Country residual & 0.006 & 0.038 & 3.610 & 155 \\
\hline Real estate residual & 0.007 & 0.215 & 5.411 & 155 \\
\hline Currency residual & -0.205 & -0.189 & 0.329 & 155 \\
\hline Common currency factor & -0.204 & -0.302 & 1.984 & 155 \\
\hline US inflation & 0.205 & 0.202 & 0.407 & 155 \\
\hline Country governance & 1.401 & 1.430 & 0.207 & 155 \\
\hline \multicolumn{5}{|c|}{ Panel (b): Firm-level control variables } \\
\hline Variable & Mean & Median & S.D. & $\mathbf{N}$ \\
\hline DE ratio & 1.855 & 1.010 & 4.395 & 51613 \\
\hline Firm size (in US\$ mil.) & 1880.210 & 677.229 & 3934.682 & 60972 \\
\hline Rate of investment & 0.035 & 0.000 & 1.546 & 21783 \\
\hline \multicolumn{5}{|c|}{ Proportion of observations with } \\
\hline REIT status dummy & 0.484 & 0.000 & 0.500 & 106000 \\
\hline
\end{tabular}

Table 3

The table presents descriptive statistics on the control variables included in our regression model, summarised over the period January 1999 to December 2011. Panel (a) contains the macroeconomic variables. The riskfree rate is the monthly total return on 1-month US Treasury bills obtained from Kenneth French's database. MSCI is the monthly total return on the MSCI world stock market index. The country residual is obtained from regressing the monthly excess (over the risk-free rate) total return on country c's main stock market index on the monthly excess total world stock market return and collecting the residuals that represent the orthogonalised country factors. The real estate residual is obtained from a projection of the monthly excess total return on country c's EPRA/NAREIT listed real estate index on the corresponding excess return on the world stock market index and the country's main stock market index and collecting the residuals that represent the orthogonalised real estate factor. The currency residual is obtained from projecting the monthly change in country $c$ 's exchange rate relative to the US\$ on the changes in all other countries' exchange rates relative to the US\$ and collecting the residuals, which we average to obtain the residual currency factor. The common currency factor is obtained from averaging the deviation from the mean predicted values of this projection (excluding the constant). US inflation is the change in the CPI index. All macroeconomic data is presented in percentage format. Country governance is the equally-weighted average of the six component scores of the World Governance Indicators obtained from the World Bank. Panel (b) contains the firmlevel control variables. DE Ratio is the debt-to-equity ratio of the sample firms. Firm size is the market capitalisation of the sample firms in millions of current US\$. The rate of investment is the annual change in net real estate investment relative to the beginning of period net real estate investment (in decimal form). REIT status is a dummy variable that takes the value of one if a firm has elected the REIT status. All firm-level data is from $S N L$. 
Descriptive statistics for the underpricing variable, full study period (1999-2011)

\begin{tabular}{lrrrr}
\hline Country & Mean & Median & S.D. & N \\
\hline Australia & 0.035 & 0.048 & 0.250 & 2859 \\
Austria & 0.024 & 0.026 & 0.274 & 776 \\
Belgium & 0.036 & 0.037 & 0.280 & 1237 \\
Canada & 0.048 & 0.036 & 0.261 & 4108 \\
Finland & 0.006 & 0.022 & 0.207 & 399 \\
France & $-0.025^{* * *}$ & -0.019 & 0.228 & 2808 \\
Germany & 0.053 & 0.048 & 0.264 & 2080 \\
Hong Kong & 0.149 & 0.148 & 0.270 & 4447 \\
Italy & $-0.030^{* * *}$ & -0.032 & 0.225 & 580 \\
Japan & $-0.131^{* * *}$ & -0.140 & 0.284 & 3949 \\
Netherlands & 0.081 & 0.074 & 0.195 & 878 \\
New Zealand & -0.001 & -0.035 & 0.290 & 310 \\
Norway & 0.041 & 0.012 & 0.181 & 244 \\
Poland & 0.087 & 0.130 & 0.174 & 223 \\
Singapore & 0.021 & 0.031 & 0.268 & 3709 \\
Spain & 0.013 & 0.004 & 0.249 & 834 \\
Sweden & $-0.030^{* * *}$ & -0.046 & 0.297 & 1480 \\
Switzerland & $-0.103^{* * *}$ & -0.025 & 0.321 & 609 \\
USA & $-0.037^{* * *}$ & -0.037 & 0.269 & 17292 \\
UK & 0.048 & 0.051 & 0.256 & 8662 \\
\hline \hline
\end{tabular}

Table 4

The table presents the descriptive statistics for the underpricing variable. The underpricing variable is the rolling 24-month correlation between the returns on the listed real estate firms in a country and the monthly change in the default spread in the corresponding country. A significant negative value indicates significant mispricing of credit exploited by the listed real estate firms in the country on average over the study period 1999 to 2011. Asterisks denote the results from a t-test for $H_{0}:$ Mean $=0$ vs. $H_{A}:$ Mean $<0$. Significance is indicated as follows: ${ }^{* * *} \mathrm{p}<0.01,{ }^{* *} \mathrm{p}<0.05,{ }^{*} \mathrm{p}<0.10$. 
Correlation table for independent variables, full study period (1999-2011)

\begin{tabular}{|c|c|c|c|c|c|c|c|c|c|c|c|c|}
\hline Variables & (1) & $(2)$ & (3) & (4) & (5) & (6) & (7) & $(8)$ & (9) & (10) & $(11)$ & (12) \\
\hline (1) MSCI & 1.00 & & & & & & & & & & & \\
\hline (2) CTRY & 0.00 & 1.00 & & & & & & & & & & \\
\hline (3) RERES & 0.00 & 0.00 & 1.00 & & & & & & & & & \\
\hline (4) FXRES & $-0.23^{*}$ & -0.00 & $-0.03^{*}$ & 1.00 & & & & & & & & \\
\hline (5) FXCOM & $-0.66^{*}$ & $-0.09^{*}$ & $-0.16^{*}$ & $0.13^{*}$ & 1.00 & & & & & & & \\
\hline (6) USIN & $0.07^{*}$ & $0.01^{*}$ & $0.07^{*}$ & $-0.05^{*}$ & $-0.15^{*}$ & 1.00 & & & & & & \\
\hline (7) UPRIC & 0.00 & $0.04^{*}$ & $0.02^{*}$ & -0.00 & -0.00 & 0.01 & 1.00 & & & & & \\
\hline (8) DE Ratio & 0.00 & -0.00 & -0.00 & $0.01^{*}$ & 0.00 & 0.01 & $-0.03^{*}$ & 1.00 & & & & \\
\hline (9) LN Firm size & $0.03^{*}$ & 0.01 & $0.02^{*}$ & $-0.06^{*}$ & $-0.03^{*}$ & $-0.03^{*}$ & $-0.04^{*}$ & $-0.11 *$ & 1.00 & & & \\
\hline (10) REIT status & -0.00 & -0.00 & -0.00 & -0.00 & 0.00 & -0.00 & $-0.05^{*}$ & $0.01^{*}$ & $0.11^{*}$ & 1.00 & & \\
\hline (11) Country governance & $-0.02^{*}$ & $-0.01 *$ & $0.04^{*}$ & $-0.03^{*}$ & $0.01 *$ & $-0.06^{*}$ & $0.09^{*}$ & $-0.08^{*}$ & $-0.10^{*}$ & $-0.13^{*}$ & 1.00 & \\
\hline (12) Rate of investment & $-0.02 *$ & 0.00 & $-0.01^{*}$ & 0.01 & $0.01^{*}$ & -0.00 & $0.02^{*}$ & $0.11^{*}$ & $-0.05^{*}$ & 0.01 & -0.01 & 1.00 \\
\hline
\end{tabular}

Table 5: The table presents the pairwise Pearson correlation coefficients between the independent variables included in our study. MSCI is the monthly total return on the MSCI world stock market index. The country residual CTRY is obtained from regressing the monthly excess (over the risk-free rate) total return on country $c$ 's main stock market index on the monthly excess total world stock market return and collecting the residuals that represent the orthogonalised country factors. The real estate residual RERES is obtained from a projection of the monthly excess total return on country c's EPRA/NAREIT listed real estate index on the corresponding excess return on the world stock market index and the country's main stock market index and collecting the residuals that represent the orthogonalised real estate factor. The currency residual FXRES is obtained from projecting the monthly change in country c's exchange rate relative to the US\$ on the changes in all other countries' exchange rates relative to the US\$ and collecting the residuals, which we average to obtain the residual currency factor. The common currency factor FXCOM is obtained from averaging the deviation from the mean predicted values of this projection (excluding the constant). USIN is unexpected US inflation from filtering the monthly change in the CPI index using an ARIMA $(0,1,1)$ specification and collecting the residual. The underpricing variable UPRIC is the rolling 24-month correlation between the returns on the listed real estate firms in country $c$ and the monthly change in the default spread in the corresponding country. DE Ratio is the debt-to-equity ratio of the sample firms. LN Firm size is the log of the market capitalisation of the sample firms. REIT status is a dummy variable that takes the value of one if a firm has elected the REIT status. Country governance is the equally-weighted average of the six component scores of the World Governance Indicators. The rate of investment is the annual change in net real estate investment relative to the beginning of period net real estate investment. The asterisk denotes significance at the $5 \%$ level. 
Regression results for global firm panel - full study period 1999-2011

\begin{tabular}{|c|c|c|c|c|}
\hline & (1) & $(2)$ & (3) & $(4)$ \\
\hline Variable & Global panel & IV panel & Residual UPRIC & UPRIC Dummy \\
\hline \multirow[t]{2}{*}{ MSCI } & $1.002^{* * *}$ & $1.036^{* * *}$ & $1.002^{* * *}$ & $0.992^{* * *}$ \\
\hline & $(0.03)$ & $(0.04)$ & $(0.03)$ & $(0.03)$ \\
\hline \multirow[t]{2}{*}{ CTRY } & $0.558^{* * *}$ & $1.317^{* * *}$ & $0.567 * * *$ & $0.567 * * *$ \\
\hline & $(0.04)$ & $(0.39)$ & $(0.04)$ & $(0.04)$ \\
\hline \multirow[t]{2}{*}{ RERES } & $0.683^{* * *}$ & $0.684^{* * *}$ & $0.685^{* * *}$ & $0.684^{* * *}$ \\
\hline & $(0.03)$ & $(0.03)$ & $(0.03)$ & $(0.03)$ \\
\hline \multirow[t]{2}{*}{ FXRES } & -0.278 & -0.295 & -0.284 & $-0.376^{* *}$ \\
\hline & $(0.19)$ & $(0.20)$ & $(0.20)$ & $(0.19)$ \\
\hline \multirow[t]{2}{*}{ FXCOM } & $0.416^{* * *}$ & $0.539^{* * *}$ & $0.414^{* * *}$ & $0.389 * * *$ \\
\hline & $(0.05)$ & $(0.09)$ & $(0.05)$ & $(0.05)$ \\
\hline \multirow[t]{2}{*}{ USIN } & $1.323^{* * *}$ & $1.481^{* * *}$ & $1.350^{* * *}$ & $1.275^{* * *}$ \\
\hline & $(0.18)$ & $(0.21)$ & $(0.18)$ & $(0.18)$ \\
\hline \multirow[t]{2}{*}{ Governance } & $-0.029 *$ & -0.022 & $-0.033^{* *}$ & $-0.026^{*}$ \\
\hline & $(0.02)$ & $(0.02)$ & $(0.02)$ & $(0.02)$ \\
\hline \multirow[t]{2}{*}{ DE Ratio } & -0.000 & -0.000 & -0.000 & -0.000 \\
\hline & $(0.00)$ & $(0.00)$ & $(0.00)$ & $(0.00)$ \\
\hline \multirow[t]{2}{*}{ LN Firm size } & $0.004^{* * *}$ & $0.004^{* * *}$ & $0.004^{* * *}$ & $0.004^{* * *}$ \\
\hline & $(0.00)$ & $(0.00)$ & $(0.00)$ & $(0.00)$ \\
\hline \multirow[t]{2}{*}{ REIT status } & $0.005^{* * *}$ & $0.005^{* * *}$ & $0.005^{* * *}$ & $0.005^{* * *}$ \\
\hline & $(0.00)$ & $(0.00)$ & $(0.00)$ & $(0.00)$ \\
\hline \multirow[t]{2}{*}{ L.UPRIC } & $-0.005^{* *}$ & & & \\
\hline & $(0.00)$ & & & \\
\hline \multirow[t]{2}{*}{ Residual UPRIC } & & & $-0.004^{* *}$ & \\
\hline & & & $(0.00)$ & \\
\hline \multirow[t]{2}{*}{ UPRIC dummy } & & & & $-0.002^{*}$ \\
\hline & & & & $(0.00)$ \\
\hline \multirow[t]{2}{*}{ Constant } & 0.023 & 0.017 & 0.030 & 0.018 \\
\hline & $(0.02)$ & $(0.02)$ & $(0.02)$ & $(0.02)$ \\
\hline Observations & 40,806 & 40,806 & 39,872 & 41,451 \\
\hline R-squared & 0.3088 & 0.286 & 0.3086 & 0.3049 \\
\hline Year dummies & Yes & Yes & Yes & Yes \\
\hline Country dummies & Yes & Yes & Yes & Yes \\
\hline Firm clusters & 566 & 566 & 565 & 571 \\
\hline Kleibergen-Paap rank LM statistic & & 101.7 & & \\
\hline Kleibergen-Paap rank Wald F statistic & & 123.6 & & \\
\hline
\end{tabular}

Table 6

A global panel of monthly excess firm returns is regressed on the inverse of the lagged underpricing variable and the macroeconomic controls as well as controls for leverage, firm size, REIT status and country-level governance (column 1). In IV Global panel (column 2), the country residual is instrumented by the lagged underpricing variable. First-stage results are not reported. The Kleibergen-Paap rank LM statistic assesses instrument relevance, the Wald F statistic assesses instrument strength. Column 3 replaces the underpricing variable calculated on raw returns with an equivalent variable calculated on the basis of returns filtered through the multi-factor international macro asset pricing model. Column 4 considers a dummy variable that takes the value of one if the firm at time $t$ exhibits an (inverse) underpricing symptom of more than $20 \%$. Robust standard errors, in parentheses, are clustered by the firm identifier. Significance is indicated as follows: *** $\mathrm{p}<0.01, * * \mathrm{p}<0.05,{ }^{*} \mathrm{p}<0.10$. 
Robustness tests on threshold for UPRIC dummy variable - full study period 1999-2011

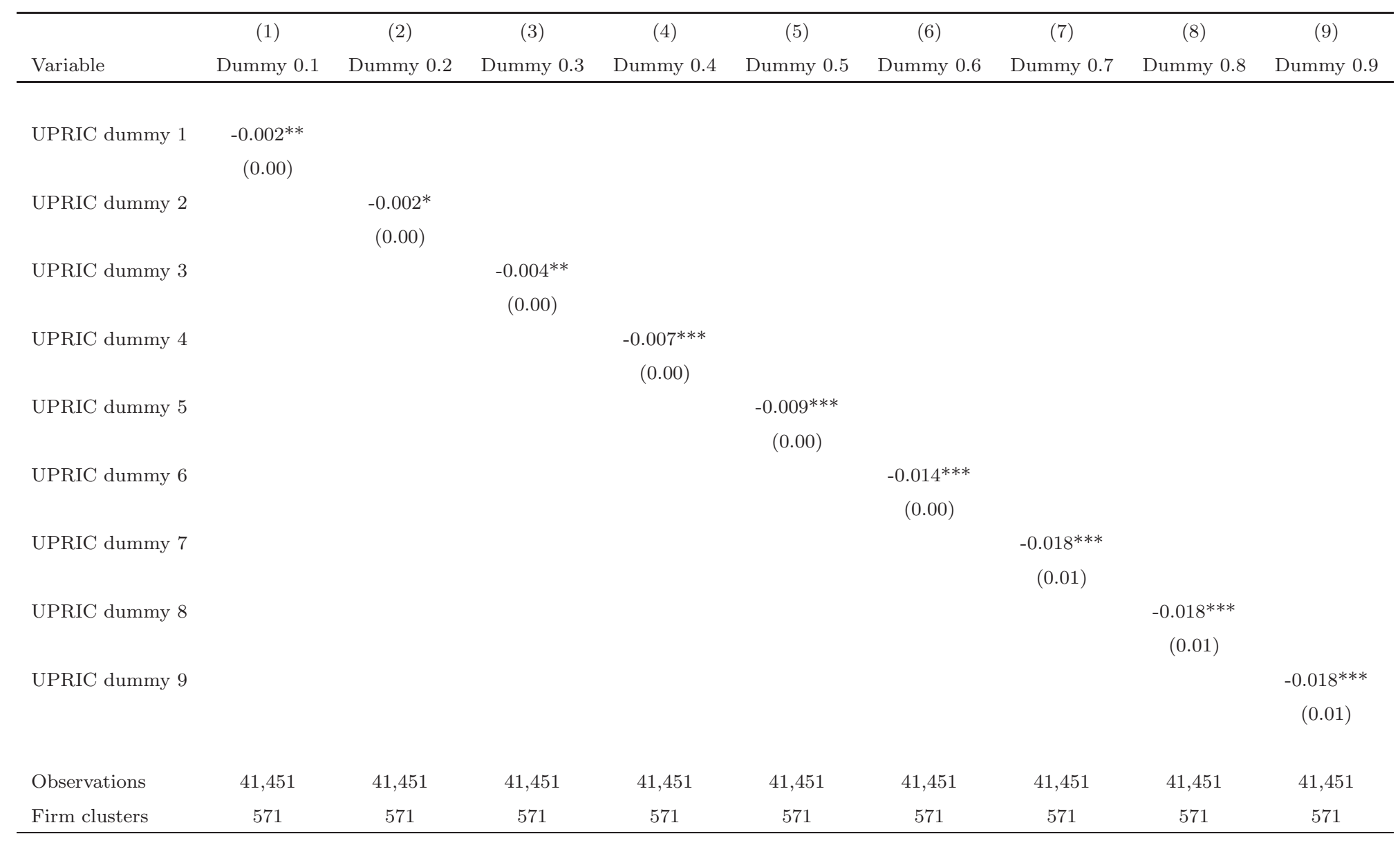

Table 7: The table presents the regression of a global panel of monthly excess firm returns on a dummy variable that takes the value of one if the underpricing variable exceeds the threshold stated in the column headers. The regression controls for all the macroeconomic factors in our main model (the world stock market, the residual country factor, foreign currency factors, US inflation as well as controls for leverage, firm size, REIT status and country level governance). We include dummy variables to capture country and year effects. Robust standard errors, in parentheses, are clustered by the firm identifier. Significance is indicated as follows: ${ }^{* *} \mathrm{p}<0.01,{ }^{* *} \mathrm{p}<0.05,{ }^{*} \mathrm{p}<0.10$. 
Robustness tests

\begin{tabular}{|c|c|c|c|c|c|}
\hline & (1) & $(2)$ & $(3)$ & (4) & (5) \\
\hline Variable & Lending cost & Business cycle & Non-linearity & Momentum & Investment growth \\
\hline \multirow[t]{2}{*}{ MSCI } & $1.006^{* * *}$ & $1.003^{* * *}$ & $1.003^{* * *}$ & $1.008^{* * *}$ & $0.896^{* * *}$ \\
\hline & $(0.03)$ & $(0.03)$ & $(0.03)$ & $(0.03)$ & $(0.04)$ \\
\hline \multirow[t]{2}{*}{ CTRYRES } & $0.577 * * *$ & $0.555^{* * *}$ & $0.558 * * *$ & $0.583^{* * *}$ & $0.201 * * *$ \\
\hline & $(0.04)$ & $(0.03)$ & $(0.04)$ & $(0.04)$ & $(0.04)$ \\
\hline \multirow[t]{2}{*}{ RERES } & $0.684^{* * *}$ & $0.683^{* * *}$ & $0.684^{* * *}$ & $0.722^{* * *}$ & $0.883^{* * *}$ \\
\hline & $(0.03)$ & $(0.03)$ & $(0.03)$ & $(0.03)$ & $(0.04)$ \\
\hline \multirow[t]{2}{*}{ FXRES } & -0.182 & -0.271 & -0.290 & $-0.391^{* *}$ & $-0.446^{* *}$ \\
\hline & $(0.20)$ & $(0.20)$ & $(0.19)$ & $(0.20)$ & $(0.22)$ \\
\hline \multirow[t]{2}{*}{ FXCOM } & $0.393^{* * *}$ & $0.417^{* * *}$ & $0.418^{* * *}$ & $0.351^{* * *}$ & $0.237^{* * *} *$ \\
\hline & $(0.05)$ & $(0.05)$ & $(0.05)$ & $(0.06)$ & $(0.06)$ \\
\hline \multirow[t]{2}{*}{ USIN } & $1.281^{* * *}$ & $1.328^{* * *}$ & $1.326^{* * *}$ & $1.127^{* * *} *$ & $1.012^{* * *}$ \\
\hline & $(0.18)$ & $(0.18)$ & $(0.18)$ & $(0.19)$ & $(0.27)$ \\
\hline \multirow[t]{2}{*}{ Governance } & $-0.044^{* * *}$ & $-0.028^{*}$ & $-0.029^{*}$ & $-0.041^{* *}$ & -0.080 \\
\hline & $(0.02)$ & $(0.02)$ & $(0.02)$ & $(0.02)$ & $(0.05)$ \\
\hline \multirow[t]{2}{*}{ DE Ratio } & -0.000 & -0.000 & -0.000 & -0.000 & 0.000 \\
\hline & $(0.00)$ & $(0.00)$ & $(0.00)$ & $(0.00)$ & $(0.00)$ \\
\hline \multirow[t]{2}{*}{ LN Firm size } & $0.004^{* * *}$ & $0.004^{* * *}$ & $0.004^{* * *}$ & $0.004^{* * *}$ & $0.004^{* * *}$ \\
\hline & $(0.00)$ & $(0.00)$ & $(0.00)$ & $(0.00)$ & $(0.00)$ \\
\hline \multirow[t]{2}{*}{ REIT status } & $0.005^{* * *}$ & $0.005^{* * *}$ & $0.005^{* * *}$ & $0.005^{* * *}$ & $0.006^{* * *}$ \\
\hline & $(0.00)$ & $(0.00)$ & $(0.00)$ & $(0.00)$ & $(0.00)$ \\
\hline \multirow[t]{2}{*}{ L.UPRIC } & $-0.005^{*}$ & $-0.005^{* *}$ & $-0.005^{* *}$ & $-0.005^{* *}$ & \\
\hline & $(0.00)$ & $(0.00)$ & $(0.00)$ & $(0.00)$ & \\
\hline \multirow[t]{2}{*}{ Lending rate } & $0.154^{* * *}$ & & & & \\
\hline & $(0.06)$ & & & & \\
\hline \multirow[t]{2}{*}{$\Delta$ Spread } & -0.008 & & & & \\
\hline & $(0.01)$ & & & & \\
\hline \multirow[t]{2}{*}{ BUSINTER } & & -0.093 & & & \\
\hline & & $(0.12)$ & & & \\
\hline \multirow[t]{2}{*}{ L.UPRIC ${ }^{2}$} & & & 0.011 & & \\
\hline & & & $(0.01)$ & & \\
\hline \multirow[t]{2}{*}{ BH6M } & & & & 0.002 & \\
\hline & & & & $(0.00)$ & \\
\hline \multirow[t]{2}{*}{ INVINTER } & & & & & $-0.002^{* * *}$ \\
\hline & & & & & $(0.00)$ \\
\hline Observations & 39,930 & 40,806 & 40,806 & 33,368 & 18,313 \\
\hline Firm clusters & 566 & 566 & 566 & 564 & 197 \\
\hline
\end{tabular}

Table 8

The table presents the robustness tests. We regress a global panel of monthly excess firm returns on the underpricing variable. The regressions control for all the macroeconomic factors and firm-level variables in our main model. Column 1 controls for two aspects of the cost of debt, the lending rate and the change in the default spread ( $\Delta$ Spread). Column 2 considers a potential interaction between unpriced credit and the business cycle by controlling for the product of the country residual and the underpricing variable in BUSINTER. Column 3 considers the possibility of non-linearities in the relationship between underpriced credit and firm performance by controlling for the square of the underpricing variable. Column 4 controls for return momentum using the 6-month buy-and-hold return BH6M on the sample firms. Column 5 considers an interaction term INVINTER, calculated between the underpricing variable and the rate of investment. We include dummy variables to capture country and year effects. Robust standard errors, in parentheses, are clustered by the firm identifier. Significance is indicated as follows: *** $\mathrm{p}<0.01,{ }^{* *} \mathrm{p}<0.05,{ }^{*} \mathrm{p}<0.10$. 
Robustness test on non-real estate stocks

\begin{tabular}{|c|c|c|}
\hline & (1) & $(2)$ \\
\hline Variable & All stocks & All stocks winsorised \\
\hline \multirow[t]{2}{*}{ MSCI } & $1.593^{* * *}$ & $1.516^{* * *}$ \\
\hline & $(0.11)$ & $(0.08)$ \\
\hline \multirow[t]{2}{*}{ CTRY } & $1.171^{* * *}$ & $1.006^{* * *}$ \\
\hline & $(0.23)$ & $(0.16)$ \\
\hline \multirow[t]{2}{*}{ FXRES } & $-6.813^{* * *}$ & $-7.729^{* * *}$ \\
\hline & $(1.23)$ & $(0.72)$ \\
\hline \multirow[t]{2}{*}{ FXCOM } & 0.337 & 0.188 \\
\hline & $(0.26)$ & $(0.22)$ \\
\hline \multirow[t]{2}{*}{ USIN } & $7.664^{* * *}$ & $6.022^{* * *}$ \\
\hline & $(0.97)$ & $(0.87)$ \\
\hline \multirow[t]{2}{*}{ WLDIN } & $31.688^{* * *} *$ & $32.001^{* * *}$ \\
\hline & $(3.67)$ & $(2.07)$ \\
\hline \multirow[t]{2}{*}{ L.UPRIC } & -0.039 & 0.111 \\
\hline & $(0.26)$ & $(0.15)$ \\
\hline \multirow[t]{2}{*}{ Constant } & $1.360^{* * *}$ & $1.335^{* * *}$ \\
\hline & $(0.09)$ & $(0.07)$ \\
\hline Observations & 107,906 & 107,906 \\
\hline Firm clusters & 1,175 & 1,175 \\
\hline Year fixed effects & Yes & Yes \\
\hline
\end{tabular}

Table 9

The table shows the robustness test for non-real estate, industrial firms. The regression replicates the base specification for this broader set of firms. Robust standard errors, in parentheses, are clustered by the firm identifier. Significance is indicated as follows: *** $\mathrm{p}<0.01, * * \mathrm{p}<0.05,{ }^{*} \mathrm{p}<0.10$. 
Time series evolution of underpricing variable, global average

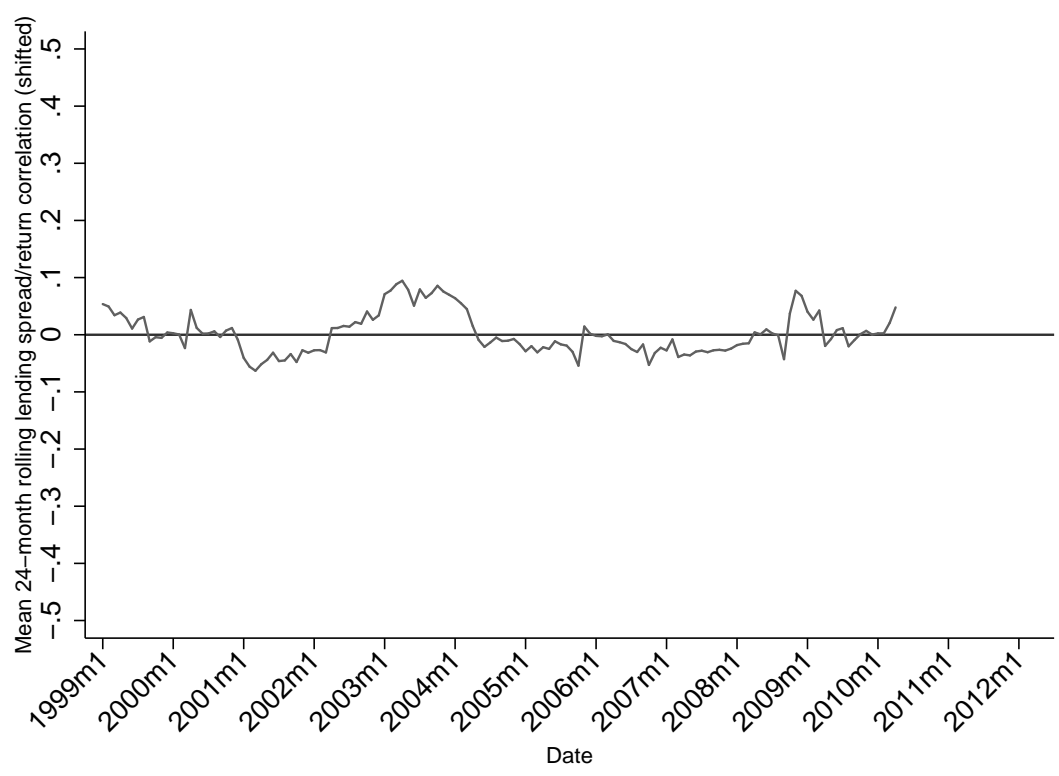

Fig. 1. The figure shows the time series evolution of the global average underpricing variables over the study period January 1999 to December 2011. The underpricing variable is the rolling 24-month correlation between the returns on the listed real estate firms in a country and the monthly change in the default spread in the corresponding country. A significant negative value indicates significant mispricing of credit exploited by the listed real estate firms in the country on average over the study period 1999 to 2011. 